TOMASZ RACHWAE

Akademia Pedagogiczna, Kraków

\title{
Efekty restrukturyzacji wybranych przedsiębiorstw przemysłowych Polski Poludniowo-Wschodniej
}

Procesy transformacji systemu społeczno-gospodarczego w Polsce, związane z przechodzeniem od centralnego systemu zarządzania gospodarką do systemu gospodarki rynkowej, wpływają w zasadniczym stopniu na gruntowne zmiany funkcjonowania poszczególnych sektorów gospodarki narodowej, przedsiębiorstw przemysłowych i usługowych oraz instytucji. Wyrazem tego jest przebudowa struktur przemysłowych, która dokonuje się w wyniku zmian funkcjonowania przedsiębiorstw przemysłowych, traktowanych jako podstawowe elementy przestrzennych form koncentracji przemysłu.

W centralnym systemie sterowania przedsiębiorstwa przemysłowe funkcjonowały w warunkach gospodarki planowej, przejawiającej się w wykonywaniu zadań wyznaczonych przez plany jednostek nadrzędnych, co wpływało na ograniczenie samodzielności przedsiębiorstw w zakresie zasobów majątkowych, wielkości i asortymentu produkcji, kierunków zbytu, zaopatrzenia w surowce i materiały, struktur organizacyjnych, zatrudnienia, a także kierunków rozwoju. W stosunkowo niewielkim stopniu sprzyjało to modernizacji procesów produkcji, podnoszeniu jakości asortymentu produkcji i wdrażaniu innowacji. We wprowadzanym systemie gospodarki rynkowej w otoczeniu przedsiębiorstw pojawiły się nowe uwarunkowania ich funkcjonowania, a mechanizmy konkurencji zaczęły mieć istotne znaczenie w zmianach kierunku działalności przedsiębiorstw oraz ich selekcji. Proces dostosowania się przedsiębiorstw przemysłowych do tych nowych warunków gospodarowania wymaga od nich przeprowadzenia procesu restrukturyzacji prowadzącego do podniesienia ich konkurencyjności. Zmiany te warunkują uczestnictwo krajowych przedsiębiorstw przemysłowych $\mathrm{w}$ globalnych procesach gospodarczych i integrację polskiego przemysłu z przemysłem światowym, zwłaszcza w drodze powiązań organizacyjnych, kapitałowych, technologicznych i wchodzenia w ukształtowane sieci rynkowe ponadnarodowych korporacji.

$\mathrm{W}$ analizie funkcjonowania przedsiębiorstw przemysłowych w okresie transformacji systemu gospodarowania kluczowego znaczenia nabiera termin ,restrukturyzacja”. W literaturze przedmiotu powszechnie przyjmuje się, że proces ten może być rozpatrywany w skali makro, czyli gospodarki narodowej, i w skali mikro, czyli przedsiębiorstw [Kuźnik 2000; Tkocz 2001]. Z. Mikołajewicz (1995) wyróżnia jeszcze mezorestrukturyzację, obejmującą sferę struktur gałęziowo-branżowych lub regionalnych, sytuując ją pomiędzy mikro- i makrorestrukturyzacją. Pojęcie „restrukturyzacja”, zdaniem większości autorów podejmujących tę problematykę, jest wieloznaczne i może być odczytywane w różny sposób [Karpiński 1986; 
Kortus 1992; Mikołajewicz 1995; Sapijaszka 1997; Nalepka 1998; Tkocz 2001]. Dlatego większość autorów stosuje definicję pośrednią, polegającą na opisie elementów, które na ten proces się składają. Do elementów najczęściej opisujących istotę restrukturyzacji można zaliczyć [Tkocz 2001]:

- świadomą, zamierzoną i celową przebudowę struktury,

- przekształcenia technologiczne, organizacyjne, funkcjonalne, ekonomiczne, kulturowe i przestrzenne w celu podniesienia efektywności, konkurencyjności, innowacyjności,

- awans cywilizacyjno-technologiczno-kulturowy,

- adaptację do warunków rynkowych,

- orientację na rynki międzynarodowe,

- ciągłość i długotrwałość.

Ze względu na przedmiot niniejszej pracy należy przyjąć definicję tego pojęcia w odniesieniu do skali mikroekonomicznej, tj. przedsiębiorstw. W warunkach utrwalonej gospodarki rynkowej termin ten może być definiowany jako proces radykalnych zmian w rożnych sferach przedsiębiorstwa polegających na jego dostosowaniu się do obecnych i przyszłych zmian w otoczeniu, których celem jest dalszy jego rozwój [Dowżycki, Sobolewski, Tłuchowski 2001]. W polskich warunkach z uwagi na trwającą transformację systemową gospodarki, restrukturyzacja ma charakter specyficzny. Dlatego najogólniej jest ona określana w literaturze jako proces dostosowywania się przedsiębiorstw do wymogów gospodarki rynkowej [Pasieczny 1997]. Według Z. Sapijaszki [1997: 18] proces restrukturyzacji to ,zmiana radykalna w co najmniej jednym spośród trzech wymiarów organizacji, tzn. zakresie działania, strukturze kapitałowej lub organizacji wewnętrznej firmy. Celem tej zmiany jest przywrócenie przedsiębiorstwu równowagi wewnętrznej i/lub równowagi z otoczeniem”. Autorka podkreśla, że proces restrukturyzacji konkretnego przedsiębiorstwa jest procesem wyjątkowym, silnie osadzonym w kontekście działania, dlatego nie ma jednego uniwersalnego modelu restrukturyzacji przedsiębiorstw. Podczas przygotowywania i realizacji procesu stosuje się podobne reguły postępowania, natomiast szczegółowe rozwiązania będą zależały od specyficznych uwarunkowań konkretnego przedsiębiorstwa. Natomiast A. Nalepka [1998] restrukturyzację przedsiębiorstwa rozumie jako systemową przebudowę, modernizację lub unowocześnienie czy uwspółcześnienie struktury organizacyjnej i zasad funkcjonowania przedsiębiorstwa. Według Z. Mikołajewicza [1995] i W. Jakóbika [1993] restrukturyzacja powinna spełniać co najmniej trzy kryteria: mieć świadomy i zamierzony charakter, być realizowana według określonego programu oraz wdrażana przy pomocy odpowiednich, dostosowanych do tego celu mechanizmów i instrumentów ekonomicznych. W świetle powyższych rozważań należy stwierdzić, że nie każda zmiana w funkcjonowaniu przedsiębiorstwa czy jego wybranych struktur (np. zatrudnienia) oznacza realizowanie procesu restrukturyzacji. Pogląd ten jest przyjmowany powszechnie przez wielu autorów [Mikołajewicz 1995; Tkocz 2001]. Termin restrukturyzacja winien być stosowany $\mathrm{w}$ odniesieniu do przedsiębiorstw, które realizują świadome, zaprogramowane, stosunkowo radykalne zmiany w swoim funkcjonowaniu i w istotny sposób przebudowują swoje struktury. Należy jednak zwrócić uwagę - za Z. Mikołajewiczem [1995] - że w zależności od stopnia nasilenia procesu restrukturyzacji można ją podzielić na umiarkowaną i radykalną. Pogląd ten stoi w opozycji z definicją Z. Sapijaszki [1997], która podkreśla „radykalność” jako istotną cechę restrukturyzacji.

Z punktu widzenia przedmiotu rozważań istotny jest podział procesu restrukturyzacji według kryterium czasowego. Wyróżnia się najczęściej dwa główne etapy tego procesu. Pierwszy etap to uchronienie się przed upadkiem (jest to tzw. restrukturyzacja ratunkowa lub 
naprawcza), natomiast drugi to restrukturyzacja rekonwalescencyjna lub rozwojowa (w zależności od stopnia zaawansowania zmian). Pierwszy etap polega na zmianie formy organizacyjno-prawnej (najczęściej przekształcenie przedsiębiorstwa państwowego w jednoosobową spółkę Skarbu Państwa) i prywatyzacji, racjonalizacji poziomu zatrudnienia, restrukturyzacji finansowej (negocjacje z bankami i wierzycielami), rezygnacji z produkcji wyrobów, które nie znajdują nabywców na wolnym rynku, pozbywanie się zbędnego majątku produkcyjnego i nieprodukcyjnego. Drugi etap to doskonalenie zasad funkcjonowania, a więc działania na rzecz obniżenia kosztów, budowanie skutecznych strategii finansowych, wprowadzanie nowych produktów i technologii, modernizacja posiadanego majątku produkcyjnego, szerokie i intensywne działania projakościowe, zwiększanie aktywności marketingowej, i wreszcie ekspansja geograficzna, wchodzenie w fuzje i przejmowanie innych przedsiębiorstw [Pasieczny 1997; Nalepka 1997, 1998].

Restrukturyzacja jest procesem wielowymiarowym, dlatego A. Nalepka [1997, 1998], za B. Pełką [1995] wyodrębnia restrukturyzację podmiotowa, tj. przekształcenia prawno-organizacyjno-ekonomiczne (utożsamia się ją zwykle ze zmianami własnościowymi) oraz restrukturyzację przedmiotową, w zakres której wchodzą przekształcenia techniczno-technologiczne i asortymentowe. F. Kuźnik [2000] wyróżnia natomiast następujące przekroje restrukturyzacji: produktów (obejmująca zmiany struktury produktowej, tj. wycofywanie starych, modernizacje i wprowadzanie nowych), technologiczną, własnościowo-kapitałową, organizacyjno-wielkościową (odzwierciedlającą proces konsolidacji przedsiębiorstw, powstawania holdingów itp.), ekologiczną (obejmującą zmiany technologiczne i procesy likwidacyjne wymuszone dbaniem o środowisko) oraz przestrzenną. L. Pakuła [1992, 2003] przyjmuje natomiast cztery podstawowe wymiary restrukturyzacji, tj. techniczną, ekonomiczną, zatrudnienia i organizacyjna. Według M. Tkocz [2001], restrukturyzacja - z punktu widzenia geograficznego - obejmuje zmiany w strukturze gałęziowej i branżowej przemysłu, oraz zmiany technologiczne, własnościowe, organizacyjne, wielkościowe i przestrzenne. Takie wymiary restrukturyzacji uwzględniane są także przez innych autorów [m.in. Zioło 1992; Makieła, Troc 1992; Czapliński 2000; Gierańczyk 2000, Mikołajewicz 2001; Rydz, Jażewicz 2001].

W świetle powyższych rozważań przedmiotem artykułu jest analiza efektów procesu restrukturyzacji przedsiębiorstw przemysłowych, występujących w ośrodkach przemysłowych Polski Południowo-Wschodniej. Analiza jest wynikiem prac badawczych nad funkcjonowaniem przedsiębiorstw przemysłowych, prowadzonych w latach 2001-2004, których podstawowym celem było określenie prawidłowości i typów zachowań badanych przedsiębiorstw pod wpływem wdrażania reguł gospodarki rynkowej. Założono, że dominującą rolę w procesie przystosowania się do nowych warunków gospodarki rynkowej odgrywają uwarunkowania zewnętrzne i wewnętrzne. Wśród uwarunkowań zewnętrznych podstawowe znaczenie mają impulsy płynące z otoczenia międzynarodowego, związane z nasilającym się procesem globalizacji działalności gospodarczej i integracji europejskiej [Domański 2001; Godziszewski 2001; Liberska 2002a, 2002b; Stryjakiewicz 1999; Rachwał 2003; Wieloński, Durydiwka 1994; Zioło 2003; Zorska 1998; Żukrowska 2001]. Uwarunkowania zewnętrzne tworzy także sytuacja krajowa, wynikająca z polityki przemysłowej państwa, przejawiająca się m.in. w nasileniu i rozmiarach procesu prywatyzacji przedsiębiorstw, wdrażaniu strategii restrukturyzacji określonych branż przemysłu oraz kształtowaniu instrumentów prawnych [Bazydło, Smętkowski 2000; Bazydło, Smętkowski, Wieloński 2001; Bałtowski 2002; Jurek-Stępień 1994; Kudełko 1997; Koźmiński 1998; Misztal 1993, 2000, 2003; Rapacki 1994; Rochnowski 2001; Wojtyna 1994; Zioło 1994, 1996a]. Do podstawowych uwarunko- 
wań wewnętrznych, tkwiących w strukturze przedsiębiorstwa, należą: rodzaj profilu produkcji, struktura wielkościowa i asortymentowa produkcji, postawy pracowników wobec zmian, jakość zarządzania, struktura organizacyjna, poziom technologiczny, stopień zadłużenia i dostępności do źródeł zasilania finansowego oraz powiązania rynkowe [Kotowicz-Jawor 1997; Misztal 1994; Parysek 1992a, 1992b; Stępień 2001; Sudoł 1997; Sudoł, Matuszak 2002; Szczepkowska 2003; Tobolska 2004]. Założono, że proces transformacji przedsiębiorstw przemysłowych odbywa się w konkretnym miejscu przestrzeni geograficznej, która jest funkcją wzajemnie uwarunkowanych elementów przestrzeni przyrodniczej, społecznej, gospodarczej i kulturowej [Zioło 1996b, 1999, 2003]. W pracy badawczej zmierzano do:

1) Określenia zmian zachowań badanych przedsiębiorstw pod wypływem uwarunkowań zewnętrznych (międzynarodowych i krajowych) i wewnętrznych w głównych zakresach funkcjonowania przedsiębiorstwa, tj.:

- strukturach własnościowo-organizacyjnych;

- poziomu i struktur zatrudnienia;

- technologii i asortymentu produkcji;

- przestrzennych powiązań rynkowych w zakresie zaopatrzenia i zbytu.

2) Oceny efektów restrukturyzacji przedsiębiorstw na podstawie kształtowania się poziomu i przemiany struktury kosztów oraz wyników finansowych, w celu wyróżnienia typów zachowań przedsiębiorstw w procesie transformacji gospodarczej.

3) Identyfikacji głównych barier i czynników wspomagających rozwój przedsiębiorstw w celu określenia przewidywanych kierunków dalszych zmian funkcjonowania.

4) Określenia prawidłowości w zakresie zmian funkcjonowania przedsiębiorstw celem wyciągnięcia wniosków o charakterze aplikacyjnym, co może być pomocne w rozwijaniu koncepcji modelowych procesów transformacji.

Materiał empiryczny zebrano głównie metodą wywiadu, w którym wykorzystano specjalnie w tym celu skonstruowany kwestionariusz do badań zmian funkcjonowania przedsiębiorstwa [Rachwał 2001a], opracowany na podstawie stosowanego szczególnie w ośrodku krakowskim, kwestionariusza Pakuły [1967]. Wykorzystano także dorobek ośrodka łódzkiego w zakresie problematyki badawczej przedsiębiorstwa przemysłowego, w szczególności kwestionariusz Riley’a i Pączki [Pączka 1994a,b].

W doborze przedsiębiorstw do badań empirycznych przyjęto następujące kryteria:

- zróżnicowanie branżowe przedsiębiorstw, przy czym szczególną uwagę zwrócono na te działy, których znaczenie w strukturze przemysłu przetwórczego w regionie jest duże,

- wielkość potencjału przemysłowego - duże przedsiębiorstwa powyżej 250 zatrudnionych,

- funkcje pełnione w strukturze gospodarczej (krajowe i międzynarodowe),

- położenie przestrzenne,

- zróżnicowanie form własności - w badanej grupie znalazły się przedsiębiorstwa państwowe niesprywatyzowane oraz przedsiębiorstwa funkcjonujące w formie spółek:

a) z dominującym udziałem Skarbu Państwa,

b) z dużym udziałem inwestorów finansowych,

c) z udziałem kapitału zagranicznego,

d) w których kontrolny pakiet akcji posiadają pracownicy (akcjonariat pracowniczy),

e) w których kontrolny pakiet akcji posiada inwestor branżowy,

f) z rozproszonym akcjonariatem pomiędzy drobnych akcjonariuszy. 


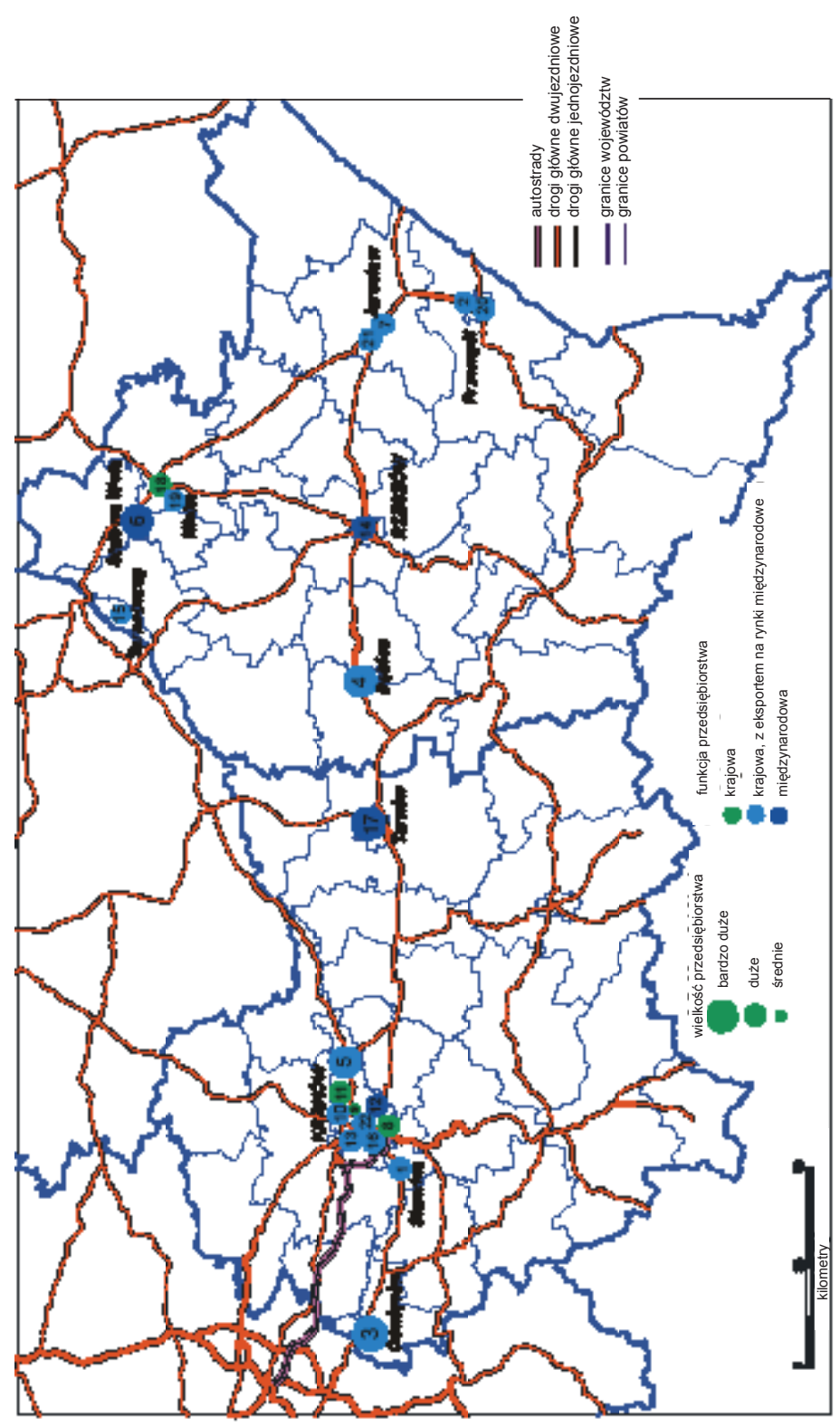

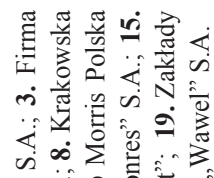

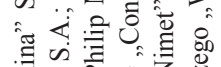

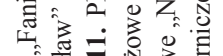

ब.

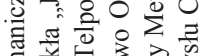

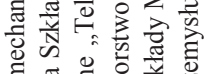

旁过管

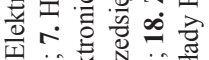

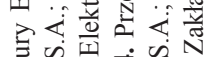

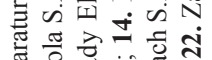

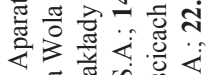

要

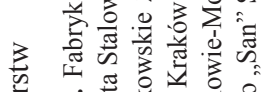

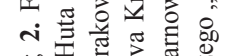

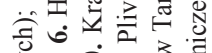

花我

का in

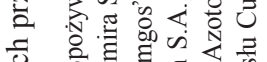

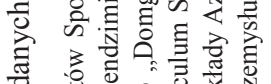

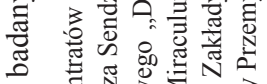

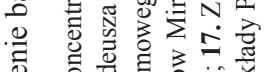

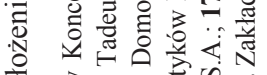

융

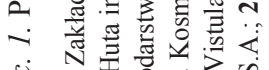

N N

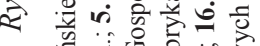

过 00

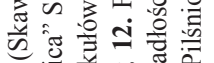

次

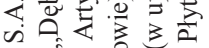

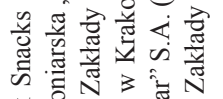

节 ô․

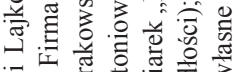

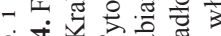

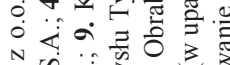

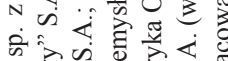

के 的苛言的

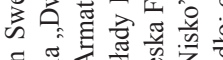

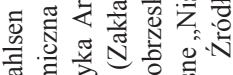

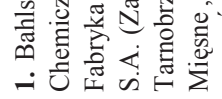


Badaniami empirycznymi objęto 22 przedsiębiorstwa Polski Południowo-Wschodniej, które spełniają powyższe kryteria i udostępniły dane o swojej działalności. Analizowane przedsiębiorstwa funkcjonowały w strukturze dziewięciu wiodących ośrodków przemysłowych: krakowskiego, oświęcimskiego, tarnowskiego, dębickiego, stalowowolskiego, tarnobrzeskiego, rzeszowskiego, jarosławskiego, przemyskiego (ryc. 1).

Analiza procesu funkcjonowania badanych przedsiębiorstw przemysłowych w latach transformacji gospodarczej wykazała jego dużą złożoność w zakresie ich przystosowania do nowych warunków gospodarki rynkowej. Różny sposób przystosowania analizowanych przedsiębiorstw nawiązywał do ich podatności na procesy dostosowawcze, przejawiającej się w ich zróżnicowaniu w zakresie formy i czasu prywatyzacji, rozmiarów potencjału produkcyjnego, funkcji pełnionych w strukturze gospodarczej, profilu prowadzonej działalności oraz formułowania i realizowania różnych strategii dostosowawczych. Z punktu widzenia realizacji celu pracy istotne znaczenie miały zmiany: struktur własnościowo-organizacyjnych, poziomu i struktur zatrudnienia, technologii i asortymentu produkcji, powiązań przestrzenno-produkcyjnych oraz struktury kosztów produkcji.

Analiza procesów restrukturyzacji własnościowej wykazała, że badane przedsiębiorstwa poddane były różnym ścieżkom prywatyzacji, a mianowicie: sprzedaż inwestorom zagranicznym, prywatyzacja w ramach Programu Powszechnej Prywatyzacji i akcjonariatu pracowniczego, sprzedaż akcji na giełdzie papierów wartościowych, natomiast niektóre z nich nadal pozostały własnością państwową. Decydujący wpływ na czas rozpoczęcia i przyjęte ścieżki zmian struktury własnościowej miała dotychczasowa kondycja ekonomiczna - zgodnie z założeniami programu proces prywatyzacji rozpoczęto od najlepszych pod względem finansowym i zdolności produkcyjnych przedsiębiorstw. Wśród badanych przedsiębiorstw zaznaczyły się dwa typy zachowań. Przedsiębiorstwa sprywatyzowane, pod wpływem nowego właściciela, szybciej wdrażały strategie restrukturyzacji, natomiast przedsiębiorstwa pozostające nadal własnością państwa wprowadzały tylko doraźne zmiany, stosując swoistą strategię oczekiwania na dotacje budżetowe lub potencjalnego inwestora, który wytyczy nowe cele strategiczne rozwoju. W wyniku badań empirycznych stwierdzono, że szybciej do nowych warunków dostosowywały się przedsiębiorstwa sprywatyzowane z udziałem inwestorów zagranicznych (takie jak: „Pliva”, „Dębica”, „Philips Morris” Polska), którzy wnosili określonej wielkości kapitał, stosownie do założonych celów rozwojowych. Słabiej procesy restrukturyzacji zaznaczały się w przedsiębiorstwach sprywatyzowanych w ramach Programu Powszechnej Prywatyzacji (np. Zakłady Mięsne „Nisko”, „Conres”), akcjonariatu pracowniczego („Wawel”) lub zaoferowane poprzez giełdę drobnym inwestorom („Vistula”). Ze względu na brak dopływu kapitału w odpowiedniej wysokości przedsiębiorstwa prywatyzowane tymi trzema ścieżkami wykorzystały swoje dotychczasowe możliwości rozwoju i rozpoczęły poszukiwania inwestora strategicznego. W procesie zmian struktury własnościowej zapewnienie odpowiedniego źródła zasilania finansowego przez właściwie dobranego inwestora strategicznego prowadzi do pozytywnych efektów procesu restrukturyzacji.

Ze zmianami własnościowymi ściśle wiąże się kwestia zmian nazw przedsiębiorstw. Pomijając fakt zmian wynikających z przekształceń przedsiębiorstwa państwowego w spółkę prawa handlowego i wynikającej z tego konieczności dodania do nazwy dopisku S.A. (lub sp. z o.o.), należy zwrócić uwagę, że tylko w sześciu przypadkach nastąpiła zasadnicza zmiana nazwy przedsiębiorstwa. Przyczyny tych zmian były różne. W przypadku HTS pierwsza zmiana nazwy podyktowana była czynnikami politycznymi (poprzednio Huta im. Lenina). Kolejna zmiana wyniknęła zaś z faktu przejęcia koncernu Polskie Huty Stali (do którego należała HTS) przez inwestora zagranicznego LNM Holdings (po przekształ- 
ceniach Mittal Steel Co.). Odtąd huta nosi oficjalną nazwę Mittal Steel Poland - Oddział w Krakowie. W trzech przedsiębiorstwach (Krakowskie Zakłady Farmaceutyczne „Polfa” - Pliva Kraków; Skawińskie Zakłady Koncentratów Spożywczych - Bahlsen Koncentraty Spożywcze; Zakłady Przemysłu Tytoniowego w Krakowie - Philip Morris Polska) zmiana nazwy nastapiła $\mathrm{w}$ wyniku przejęcia przedsiębiorstwa przez koncern zagraniczny - na nazwę tego koncernu. W Skawińskich Zakładach Koncentratów Spożywczych zmiany te były dosyć częste, co wiązało się ze zmianami organizacyjnymi w przedsiębiorstwie, tj. podziałem na dwie spółki. Pierwotną nazwę zmieniono na Bahlsen - Koncentraty Spożywcze S.A., a następnie w wyniku podziału na Bahlsen Sweet sp. z o.o. i Lajkonik Snacks S.A. Część przedsiębiorstwa produkująca kawę, sprzedana niemieckiej firmie KORD, funkcjonuje pod nazwą Biogran sp. z o.o. Przejęcie przedsiębiorstwa przez koncern zagraniczny nie zawsze związane było z przyjęciem nazwy inwestora, przykładem jest Firma Oponiarska „Dębica”, w której zmieniono pierwotną nazwę „Stomil Dębica”, jednak inwestor nie zdecydował się na nazwę „Goodyear (Polska)”. Należy zaznaczyć, że zarówno w przypadku Dębicy, jak i Plivy zmiana nazwy związana była także z koniecznością odróżnienia się od konkurencji (licznych przedsiębiorstw funkcjonujących w kraju po nazwami Stomil i Polfa). W przypadku Sanu i HSJ inwestorzy zagraniczni nie zdecydowali się na zmianę nazwy, głównie z powodu utrwalonej pozycji marki na rynku polskim*. Całkowita zmiana nazwy nastapiła także w byłych Zakładach Chemicznych „Oświęcim” (zmiana nazwy na Firma Chemiczna „Dwory” S.A. nastapiła w wyniku uchwały Walnego Zgromadzenia Akcjonariuszy, na którym decydujący głos mieli przedstawiciele NFI i Skarbu Państwa). W niektórych firmach przeprowadzono niewielkie korekty nazwy, np. Zakłady Azotowe w Tarnowie na Zakłady Azotowe w Tarnowie-Mościcach (w nawiązaniu do przedwojennej historii zakładów związanej z pomysłodawcą wybudowania fabryki prezydentem Ignacym Mościckim), Zakłady Metalowe „Nimet-Ursus” zmiana na Zakłady Metalowe „Nimet” (w związku z wyodrębnieniem się ze struktury organizacyjnej Ursusa), Vistula zrezygnowała z używania długiej nazwy Zakłady Przemysłu Odzieżowego „Vistula” na rzecz krótkiej nazwy Vistula S.A.

Zmiany struktury własnościowej, mające na celu podniesienie efektywności funkcjonowania, prowadziły do przemian istniejących do tej pory struktur organizacyjnych. Najbardziej istotne zmiany struktur organizacyjnych stwierdzono w przedsiębiorstwach sprywatyzowanych. Najpoważniejsze zmiany organizacyjne wystąpiły w przedsiębiorstwach przejętych przez inwestorów zagranicznych, polegały one na dostosowaniu ich struktury organizacyjnej do standardów koncernu (np. „Pliva”, „Philips Morris” Polska). Także bardzo duże przedsiębiorstwa niesprywatyzowane, pozostające własnością Skarbu Państwa (np. HTS, Huta Stalowa Wola) przeszły gruntowne zmiany struktury organizacyjnej, związane z wydzielaniem działów przedsiębiorstw w postaci spółek-córek i tworzeniem rozbudowanych grup kapitałowych. Natomiast niewielkie zmiany struktur organizacyjnych zaznaczyły się w przedsiębiorstwach niesprywatyzowanych o mniejszym potencjale (np. „Ponar”, „Fanina”, Zakłady Płyt Pilśniowych); przejawiały się one we wzmocnieniu działów związanych z działalnością marketingową i zarządzaniem zasobami ludzkimi.

Jednym z najistotniejszych czynników decydujących o powodzeniu procesu restrukturyzacji przedsiębiorstwa jest czynnik ludzki. To pracownicy są realizatorami wszelkich zmian, stąd tak duże znaczenie mają ich dążenia, postawy i cechy: wykształcenie, posiada-

\footnotetext{
* Należy zwrócić uwagę, że HSJ po fuzji z Hutą Szkła Antoninek w 2002 r. prowadzona jest przez spółkę Owens-Illinois Polska S.A., a „San” po odkupieniu udziałów od United Biscuits przez koncern Danone prowadzony był pod nazwą spółki przejmującej, czyli LU Polska S.A., jednak nazwy te po formalnych zmianach były nadal używane z przyczyn marketingowych (m.in. na opakowaniach towarów).
} 
ny zasób wiedzy i umiejętności, doświadczenie (staż pracy), przedsiębiorczość, zdolność wchłaniania innowacji i inne. Równie ważna jest umiejętność zdobywania nowych umiejętności i podnoszenia kwalifikacji. Wśród zasobów ludzkich przedsiębiorstwa szczególną rolę zajmuje kierownictwo, zwłaszcza jego zdolności przewidywania, umiejętności organizatorskie i kreatywność, od której zależy jakość i tempo wprowadzanych przedsięwzięć restrukturyzacyjnych. W systemie centralnego sterowania gospodarką, ze względu na przyjęte w nim założenia dostępności pracy dla wszystkich, nie przywiązywano zbyt dużej wagi do racjonalności poziomu zatrudnienia [Koźmiński 1998; Stępień 2001]. W efekcie analizowane przedsiębiorstwa u progu transformacji charakteryzowały się - podobnie jak inne przedsiębiorstwa w kraju - poziomem zatrudnienia znacznie przewyższającym potrzeby wynikające ze skali produkcji. Dlatego w latach transformacji poszczególne przedsiębiorstwa znacznie redukowały swoje zatrudnienie. Spadek zatrudnienia był zróżnicowany, czego wyrazem jest wahający się wskaźnik dynamiki od 77\% w PMP do 8\% w Telpodzie (ryc. 2).

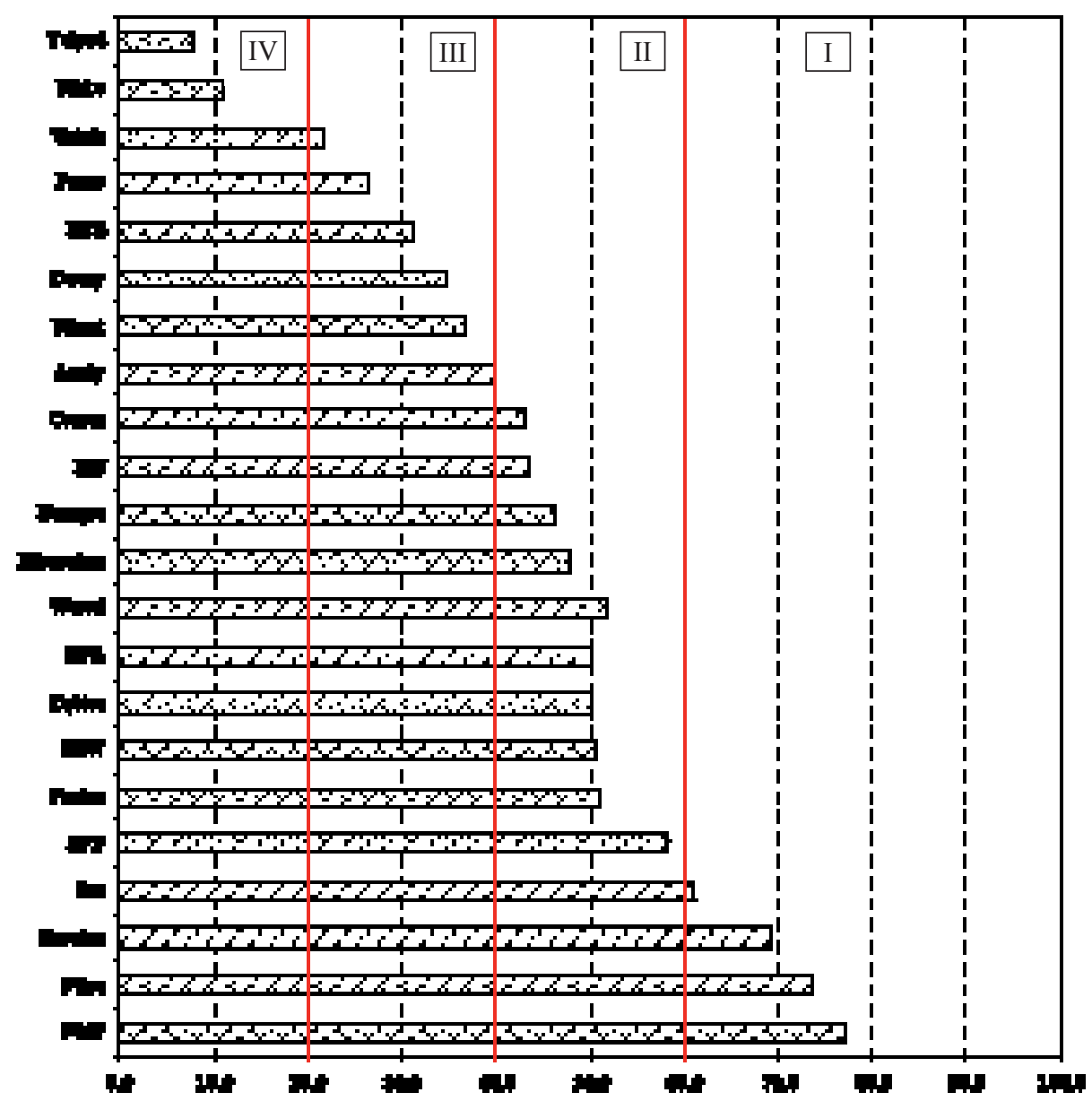

Ryc. 2. Dynamika zatrudnienia przedsiębiorstw w okresie badawczym (w \%)

Źródło: opracowanie własne na podstawie danych przedsiębiorstw 
Ze względu na wielkość wskaźnika dynamiki zatrudnienia w badanej grupie przedsiębiorstw można wyróżnić ich cztery typy:

1) o małym spadku zatrudnienia (wskaźnik dynamiki 60-80\%): PMP, „Pliva”, Skawina, „San” (razem 4 przedsiębiorstwa),

2) o umiarkowanym spadku zatrudnienia (wskaźnik dynamiki 40-60\%): ZPP, „Fanina”, HSW, „Dębica”, KFA, „Wawel”, Miraculum, „Domgos”, HSJ, „Conres”, Azoty (11),

3) o dużym spadku zatrudnienia (wskaźnik dynamiki 20-40\%): „Nimet”, „Dwory”, HTS, „Ponar”, Vistula (5),

4) o bardzo dużym spadku zatrudnienia (wskaźnik dynamiki 0-20\%): „Nisko”, „Telpod” (2).

Największa skala redukcji była w przedsiębiorstwach należących do Skarbu Państwa (np. „Telpod”, „Nimet”, „Ponar”, HTS), najmniejsza zaś w przedsiębiorstwach sprywatyzowanych z udziałem inwestorów zagranicznych („Pliva”, „Philips Morris” Polska), co wynikało głównie z zawartych umów społecznych w momencie prywatyzacji. W grupie przedsiębiorstw o bardzo dużym spadku zatrudnienia znalazły się dwa przedsiębiorstwa („Nisko”, „Telpod"), będące pod koniec okresu badawczego w stanie upadłości, w których przebieg procesu restrukturyzacji był specyficzny. Upadłość „Niska” wynika z faktu błędnego wyboru inwestora strategicznego, który nie był zainteresowany restrukturyzacją i rozwojem zakładów, natomiast przyczyna upadłości Telpodu tkwi w specyfice branży elektronicznej, przeżywającej w latach transformacji gospodarczej ostry kryzys, który - według kierownictwa firm tej branży - był nie do pokonania bez specjalnego programu rządowego wobec tego sektora [Rachwał 2001b, c].

W przebiegu zmian poziomu zatrudnienia zaznaczała się prawidłowość, polegająca na wystąpieniu trzech faz redukcji zatrudnienia - dwóch (1989-1992, 1998-2001) o dużym spadku zatrudnienia i jednej (1993-1997) o względnej stabilizacji lub małym spadku zatrudnienia. Redukcja występujących wcześniej przerostów zatrudnienia odbywała się przy równoczesnym podnoszeniu jakości kapitału ludzkiego w przedsiębiorstwach, dzięki rozbudowanemu systemowi szkoleń, podnoszących kwalifikacje pracowników.

Proces restrukturyzacji zatrudnienia oznacza nie tylko racjonalizacje poziomu zatrudnienia, ale także zmiany jego struktur, tak aby najefektywniej wykorzystywać zasoby pracy w przedsiębiorstwie i tym samym zapewnić jak największą efektywność jego funkcjonowania. Do szczególnie ważnych struktur zatrudnienia w przedsiębiorstwie należy zaliczyć: stosunek pracowników zatrudnionych na stanowiskach robotniczych (produkcyjnych) do pracowników nierobotniczych (umysłowych), strukturę wykształcenia, płci, wieku i stażu pracy. Analiza danych o zmianach w strukturach zatrudnienia wskazuje, że redukcje zatrudnienia obejmowały w większym stopniu grupę pracowników zatrudnionych na stanowiskach robotniczych niż grupę pracowników umysłowych, natomiast nowe przyjęcia do pracy przeważały w grupie pracowników umysłowych, co prowadziło do spadku udziału pracowników na stanowiskach pracowniczych w ogólnej liczbie pracowników. Korzystne zmiany nastąpiły w strukturze zatrudnienia według wykształcenia pracowników, polegające na spadku udziału pracowników z wykształceniem podstawowym na rzecz pracowników z wykształceniem zasadniczym zawodowym i średnim (na stanowiskach robotniczych), a także wzroście udziału pracowników z wykształceniem wyższym na stanowiskach nierobotniczych. Analiza struktur zatrudnienia według płci wskazuje zaś na przewagę spadku zatrudnienia kobiet nad mężczyznami. W badanych przedsiębiorstwach nie następował proces odmładzania struktur wieku pracowników, w niektórych przedsiębiorstwach państwowych (głównie byłych dużych, jak HTS) nastąpił proces wzrostu średniej wieku i stażu pracy zatrudnionych. 
Ważną rolę w podniesieniu konkurencyjności przedsiębiorstwa odgrywa restrukturyzacja technologiczna. Zmiany w technologii produkcji pozwoliły na aktywne przekształcenia asortymentu produkcji, co przejawiało się z reguły w dążeniu do zwiększenia spójności asortymentu i specjalizacji produkcji, poprzez utrzymanie bądź zmniejszenie szerokości asortymentu, a także pogłębienie asortymentu produkcji w wyniku wprowadzenia nowych, lepszych jakościowo wyrobów o tych samych parametrach użytkowych lub zwiększenia liczby typów produkowanych wyrobów. Najbardziej istotne zmiany technologiczne nastąpiły w przedsiębiorstwach sprywatyzowanych, głównie z udziałem inwestorów zagranicznych, w których zapewnione były źródła finansowania modernizacji tego majątku (np. „Pliva”, Philips Morris Polska, „Dębica”, Huta Szkła Jarosław). Przedsiębiorstwa, które nie wprowadziły zmian technologicznych, były w latach transformacji w rękach państwowych (np. „Ponar”, „Telpod”, „Nimet”). Zmiany technologiczne w przedsiębiorstwach wpłynęły także na zmniejszenie się negatywnej presji na środowisko przyrodnicze, co wynikało zarówno ze zmniejszenia wielkości produkcji, jak i inwestycji w technologie proekologiczne, w wyniku wdrażania systemów zarządzania jakością środowiska, zakończonych z reguły przyznaniem certyfikatu ISO 14001 (w przypadku „Plivy”, Zakładów Azotowych w Tarnowie i „Dworów” skreśleniem z listy największych trucicieli środowiska).

Wdrażanie reguł gospodarki rynkowej wpłynęło na przekształcenie istniejącej wcześniej sieci powiązań przestrzenno-produkcyjnych, które przejawiały się w zmianie kierunków zaopatrzenia i zbytu. Zmiany w kierunkach zaopatrzenia polegały głównie na rozszerzeniu powiązań, przy czym najczęściej nowe źródła zaopatrzenia znajdowały się poza granicami kraju. Stwierdzono, że główną przyczyną wzrostu powiązań z dostawcami zagranicznymi była zmiana stosunków własnościowych, włączanie się analizowanych przedsiębiorstw w struktury koncernów międzynarodowych oraz spełnianie przez nich wysokich wymagań jakościowych. Rozszerzenie kierunków zbytu przedsiębiorstw było możliwe dzięki wprowadzeniu innowacji produktowych, które ściśle związane były z wcześniejszym unowocześnieniem majątku produkcyjnego. W wyniku badań empirycznych stwierdzono, że kierunki powiązań przedsiębiorstw w zakresie zbytu wykazywały się zmiennością, co wpływało na niestabilność przychodów, a w wielu przedsiębiorstwach utrudniało proces restrukturyzacji (szczególnie w zakresie inwestycji w technologię produkcji). W grupie przedsiębiorstw powiązanych z inwestorami zagranicznymi (np. „Dębica”, „Pliva”) jako korzystne zjawisko zaznaczyło się rozszerzanie rynków zbytu, w tym także zagranicznych, poprzez włączenie produktów w sieci marketingowe ponadnarodowych korporacji.

Zmiany uwarunkowań makroekonomicznych oraz dążenie do podniesienia konkurencyjności produktów wypłynęły negatywnie na wzrost wskaźnika poziomu kosztów. Wpływa to na ograniczenie działalności inwestycyjnej przedsiębiorstw, co w rezultacie w coraz większym stopniu uzależnia przedsiębiorstwa od zewnętrznych, głównie zagranicznych źródeł finansowania. W strukturze kosztów zaznacza się z jednej strony korzystna prawidłowość przejawiająca się w zmniejszeniu się udziału zużycia materiałów i energii oraz wynagrodzeń i świadczeń dla pracowników, z drugiej zaś - we wzroście udziałów kosztów usług obcych i amortyzacji.

Oceniając zmiany zachowań przedsiębiorstw przemysłowych w procesie transformacji, należy odpowiedzieć na pytanie, jakie są efekty finansowe przeprowadzonych zmian. W celu oceny efektów finansowych restrukturyzacji przedsiębiorstw posłużono się powszechnie stosowanymi [Nowak 2001; Nalepka 2000] wskaźnikami wyniku finansowego przedsiębiorstw (zysku lub straty) netto. 
Przyjmując jako kryterium wynik finansowy przedsiębiorstw wyróżniono trzy grupy przedsiębiorstw (tab. 1). Pierwszą grupę przedsiębiorstw, które w latach 2001-2002 wykazały dodatni wynik finansowy, reprezentują: „Dębica”, HSJ, Miraculum, „Pliva”, PMP, Vistula oraz „Domgos” ${ }^{\prime *}$ Przedsiębiorstwa te miały dodatnie wszystkie wskaźniki wyniku finansowego oraz dodatnie wartości wskaźników rentowności. Należy zwrócić uwagę, że tylko w PMP, Wawelu i Vistuli zyski z roku 2001 były wyższe niż z 2000. W pozostałych przedsiębiorstwach zauważalna była tendencja do spadku wielkości zysków.

Analizując wyniki finansowe drugiej grupy sześciu przedsiębiorstw o nieustabilizowanej sytuacji finansowej, wykazujących tylko w jednym z przyjętych lat dodatni wynik finansowy (,Azoty”, „Dwory”, HTS, „Nisko ”**, „San”, ZPP), należy wskazać, że wyniki finansowe w 2000 r. miały dodatnie, natomiast w 2001 r. ujemne. Oznacza to pogarszanie się sytuacji ekonomiczno-finansowej tych przedsiębiorstw, straty w drugim roku były nieproporcjonalnie wyższe od zysków w roku poprzednim, np. w „Azotach” w 2000 r. zysk netto wyniósł +14,3 mln zł, zaś w 2001 r. strata aż 186,5 mln zł; natomiast w „Sanie” odpowiednio $+1,5 \mathrm{mln}$ zł i $-12,8 \mathrm{mln}$ zł.

Tabela 1. Wyniki finansowe przedsiębiorstw (w tys. zł)

\begin{tabular}{|c|c|c|}
\hline Przedsiębiorstwo & 2000 & 2001 \\
\hline Azoty & 14308,4 & $-186525,6$ \\
\hline Conres & $-218,4$ & $-169,4$ \\
\hline Dębica & 46868,0 & 8943,0 \\
\hline Domgos $^{i}$ & 692,1 & 140,3 \\
\hline Dwory & 9102,2 & $-39912,0$ \\
\hline Fanina & $-294,0$ & $-1693,3$ \\
\hline HSJ & 46679,1 & 39338,1 \\
\hline HSW $^{\mathrm{ii}}$ & $-43916,1$ & $-96216,8$ \\
\hline $\mathrm{HTS}^{\mathrm{ii}}$ & 76179,2 & $-402604,6$ \\
\hline KFA & $-16062,0$ & $-4012,6$ \\
\hline Miraculum & 1880,7 & 350,9 \\
\hline Nisko $^{\text {iii }}$ & 148,3 & $-7174,4$ \\
\hline Pliva & 30773,0 & 9578,3 \\
\hline PMP & 47559,3 & 118316,8 \\
\hline San & 1524,9 & $-12774,2$ \\
\hline Skawina $^{\text {iiii }}$ & $-8131,5$ & $-7198,0$ \\
\hline Telpod & $-2600,0$ & $-2540,0$ \\
\hline Vistula & 6120,0 & 8842,0 \\
\hline Wawel & 3073,0 & 4077,0 \\
\hline ZPP & 62,8 & $-3372,7$ \\
\hline
\end{tabular}

W tabeli nie uwzględniono przedsiębiorstw „Nimet”, „Ponar”, w stosunku do których została ogłoszona upadłość, w ostatnich latach funkcjonowania ponosiły znaczne straty.

i dla „Domgosu” przyjęto dane z lat 1998-1999

ii ze względu na charakter struktury organizacyjnej dane dotyczą grupy kapitałowej

iii dla Niska przyjęto dane z lat 1997-1998

iiii ze względu na podział przedsiębiorstwa dane sumaryczne dla Bahlsen Sweet sp. z o.o. i Lajkonik Snacks S.A.

Źródło: opracowanie własne na podstawie danych uzyskanych w przedsiębiorstwach, sprawozdań rocznych i Monitorów Polskich B

Do trzeciej grupy przedsiębiorstw wykazujących w obydwu latach straty zaliczono osiem przedsiębiorstw: „Conres”, „Fanina”, HSW, KFA, „Nimet”, „Ponar”, Skawina, „Telpod”. W stosunku do trzech przedsiębiorstw z tej grupy („Nimet”, „Ponar”, „Telpod”) ogłoszono

" Dla „Domgosu” przyjęto dane z lat 1998-1999. Z informacji uzyskanych w drodze wywiadu (bez konkretnych danych liczbowych) przedsiębiorstwo w kolejnych latach 2000-2001 ponosiło straty.

** Dla „Niska” przyjęto dane z lat 1997-1998. Z informacji uzyskanych w drodze wywiadu przedsiębiorstwo w kolejnych latach 1999-2001 ponosiło bardzo wysokie straty, co było bezpośrednią przyczyną rozpoczęcia procesu upadłościowego. 
upadłość, a ich majątek został zaoferowany przez syndyka firmom, które na jego bazie nie podjęły produkcji o tym samym profilu, co upadłe przedsiębiorstwa. Wykorzystano jedynie część maszyn i urządzeń do prac o charakterze usługowym (remontowno-naprawczym) oraz tereny i budynki produkcyjne, można więc mówić w tym wypadku o adaptacji dezindustrializującej [wg Stryjakiewicz 1999]. Trzy przedsiębiorstwa z tej grupy (KFA, „Conres”, Skawina) wykazywały nieznaczne zmniejszenie strat, natomiast dwa (HSW, „Fanina”) cechowały się zwiększeniem strat.

W wyniku przeprowadzonej analizy empirycznej zmian struktur własnościowo-organizacyjnych, zatrudnienia, zmian technologicznych i asortymentowych produkcji, powiązań przestrzenno-produkcyjnych oraz wybranych elementów analizy finansowej wyróżniono trzy typy zachowań przedsiębiorstw przemysłowych w procesie transformacji gospodarczej. Typ A reprezentują przedsiębiorstwa rozwijające się, które przeszły pomyślnie pierwszy etap tzw. restrukturyzacji naprawczej. Wśród nich wyróżniono 2 podtypy. Podtyp A1 reprezentują przedsiębiorstwa powiązane z kapitałem zagranicznym, które weszły na ścieżkę trwałego rozwoju, zaś podtyp A2 reprezentują przedsiębiorstwa, których dynamiczny rozwój jest uzależniony od dalszej restrukturyzacji technologicznej produkcji. Przedsiębiorstwa typu A1, do których zaliczono „Dębicę”, HSJ, „Plivę” i PMP charakteryzują się dobrą sytuacją finansową i bardzo dużym stopniem zaawansowania zmian technologicznych. W ich funkcjonowaniu w procesie transformacji gospodarczej należy także odnotować następujące zmiany: małe lub umiarkowane redukcje zatrudnienia oraz zmiany w asortymencie produkcji, polegające bądź na pogłębieniu bądź na poszerzeniu i pogłębieniu asortymentu. W zakresie zmian w kierunkach zbytu cechują się one rozszerzeniem lub zmiennością rynków zbytu, natomiast w zakresie zmian w źródłach zaopatrzenia przedsiębiorstwa te wybierały strategię zarówno utrzymania jak i rozszerzenia dotychczasowych powiązań. Przedsiębiorstwa typu A2 reprezentują Miraculum, Vistula i „Wawel”, będące w dobrej sytuacji finansowej i charakteryzujące się dużym stopniem zaawansowania zmian technologicznych. Charakteryzowały się one podobnymi, umiarkowanymi zmianami zatrudnienia (wyjątek stanowi Vistula, gdzie zmiany te były duże, głównie w wyniku zmian organizacyjnych, polegających na wyodrębnianiu spółek zależnych) oraz strategiami pogłębienia lub poszerzania i pogłębiania asortymentu produkcji. Rozszerzały one także powiązania w zakresie źródeł zaopatrzenia i kierunkach zbytu (z wyjątkiem Miraculum, w którym stwierdzono brak istotnych zmian w zasięgach zbytu spowodowany specyfiką asortymentu produkcji, nastawioną na tzw. rynki wschodnie). Wśród przedsiębiorstw zaliczonych do typu A2 jest Vistula, w której szanse związane z przejściem pierwszego etapu restrukturyzacji zostały częściowo zaprzepaszczone. Wynikało to z przejęcia władzy w przedsiębiorstwie w 2003 r. przez inwestorów zagranicznych, którzy nakreślili nowe - jak się okazało błędne - kierunki rozwoju przedsiębiorstwa, co doprowadziło do trudnej sytuacji finansowej przedsiębiorstwa*.

Typ B reprezentują przedsiębiorstwa nadal poszukujące dróg rozwoju, które nie zakończyły jeszcze pierwszego etapu restrukturyzacji naprawczej. Ich dalszy rozwój zależeć będzie od wystapienia wielu barier i czynników wspomagających rozwój, m.in. dalszych przemian własnościowych, w tym przejęcia przez dobrze dobranych inwestorów strategicznych i związanych z tym inwestycji w technologie produkcji oraz zmian popytu na produkty wytwarzane przez te przedsiębiorstwa. Wyróżniono tu dwa podtypy. Podtyp B1 reprezentują te przedsiębiorstwa, które dzięki przeprowadzonym dużym zmianom technologicznym mają szanse na

${ }^{*}$ Vistula musiała po raz kolejny przeprowadzić restrukturyzację finansową (w tym negocjacje z wierzycielami) i - odzyskując zaufanie inwestorów i kontrahentów - wdrożyć nową strategię rozwoju. 
przejście do etapu tzw. restrukturyzacji rozwojowej, zaś podtyp B2 te, których dalsze istnienie i rozwój jest uwarunkowane znalezieniem źródeł finansowania inwestycji technologicznych. Przedsiębiorstwa należące do typu B1, do których zaliczono Azoty, „Conres”, „Dwory”, HTS, San*, ZPP, KFA, Skawinę, cechowały się dużym stopniem zaawansowania zmian technologicznych oraz, w większości przypadków, nieustabilizowaną sytuacją finansową. Tylko dwa z nich (KFA, Skawina) znajdowały się w złej sytuacji finansowej. Przedsiębiorstwa należące do tego typu charakteryzowały się różnym stopniem redukcji zatrudnienia, od umiarkowanych zmian do dużych (tj. od $80 \%$ do $20 \%$ ). Nie było jednak wśród tej grupy przedsiębiorstw o bardzo dużych redukcjach zatrudnienia. W zakresie zmian asortymentu produkcji przeważały strategie mające na celu pogłębienie asortymentu (z wyjątkiem Sanu i Skawiny), przy różnych zmianach szerokości (poszerzenie, utrzymanie, bądź zmniejszenie). Powiązania tych przedsiębiorstw w zakresie zaopatrzenia były utrzymywane bądź rozszerzane, natomiast powiązania w zakresie zbytu cechowały się w Azotach, Conresie, Dworach, HTS i Sanie zmiennościa, natomiast w ZPP i KFA brakiem istotnych zmian, a w Skawinie rozszerzeniem. Do typu B2 zaliczono trzy przedsiębiorstwa (Domgos, Fanina, HSW), które w umiarkowanym stopniu redukowały swoje zatrudnienie i wybierały różne strategie zmian w głębokości i szerokości asortymentu - pogłębienie (HSW), zmniejszenie szerokości i głębokości (Domgos) lub brak zmian w głębokości i szerokości asortymentu (Fanina). W zakresie powiązań rynkowych charakterystyczną cechą tej grupy przedsiębiorstw jest utrzymanie powiązań w zakresie zaopatrzenia i zmienność zasięgów rynków zbytu.

Typ C reprezentują przedsiębiorstwa zanikające w strukturze gospodarczej, wśród których wyróżniono jako podtyp C1 przedsiębiorstwa upadające oraz jako podtyp C2 przedsiębiorstwa upadłe. Przedsiębiorstwa typu C1 (Zakłady Mięsne Nisko, Ponar) i C2 (Nimet, Telpod), charakteryzujące się bardzo złą sytuacją finansową, nie przeprowadziły istotnych zmian w technologii produkcji (Ponar, Nimet, Telpod) lub zmiany te były niewielkie (Nisko). Redukcje zatrudnienia w tych przedsiębiorstwach były duże albo bardzo duże. Cechowała je także bierność w odniesieniu do zmian asortymentu produkcji (Nisko, Ponar, Nimet) lub poprzestanie na zmniejszeniu szerokości (Telpod). W zakresie powiązań rynkowych charakterystyczne jest utrzymanie dotychczasowych powiązań zaopatrzenia przez Ponar, Nimet i Telpod i ich rozszerzenie w Nisku (gdzie główną przyczyną rozszerzania tych zasięgów nie była dbałość o jakość bądź korzystniejszą cenę, ale brak możliwości spłaty zobowiązań dotychczasowym dostawcom) oraz zwężeniem zasięgów rynków zbytu (z wyjątkiem Ponaru, cechującego się zmiennością). Sytuacja przedsiębiorstw podtypu C1 była - pod koniec okresu badawczego - o tyle korzystniejsza w stosunku do zlikwidowanych przedsiębiorstw typu C2, że istniała szansa na wykorzystanie ich majątku do dalszej produkcji o podobnym profilu.

Wśród badanych przedsiębiorstw najliczniejszą grupę stanowią przedsiębiorstwa typu $\mathrm{B}$, nieco mniej liczną typu A, zaś najmniej liczną przedsiębiorstwa typu C.

W wyniku analizy można przyjąć, że najlepsze perspektywy rozwojowe mają przedsiębiorstwa włączone lub włączające się w globalne sieci przemysłowe. Najkorzystniejszą drogą rozwoju dla przedsiębiorstw należących do typu B będzie więc włączanie się w globalne sieci przemysłowe lub silne krajowe grupy kapitałowe, gdyż w nasilających się procesach globalizacji coraz trudniej będzie im samodzielnie funkcjonować na rynku, szczególnie

* W Sanie osiagnięcia pierwszego etapu restrukturyzacji, dokonane przez koncern United Biscuits, zostały zmarnowane przez kolejnego właściciela Lu Polska (koncern Danone), który po przejęciu władzy dążył do zlikwidowania przedsiębiorstwa. 
w obliczu posiadania ograniczonych zasobów kapitałowych, które można by przeznaczyć na modernizację technologii produkcji.

Wyróżnione typy zachowań różnicują przedsiębiorstwa na takie, które w swoim procesie restrukturyzacji bądź wykorzystały nowe uwarunkowania, bądź - w wyniku słabego rozpoznania mechanizmów kształtujących - nie wykorzystały szans czy wreszcie poprzez wadliwe wykorzystanie instrumentów prawnych doprowadziły do zjawisk patologicznych i ich recesji. Ponieważ wiele innych przedsiębiorstw, najczęściej tych znajdujących się w trudnej sytuacji finansowej, w najbliższym czasie musi zostać poddanych procesom restrukturyzacji, mającym na celu podniesienie poziomu konkurencyjności ich produktów, wydaje się celowe określenie ich zachowań w świetle przyjętej typologii celem obrania najlepszych dla nich rozwiązań $\mathrm{np}$. w zakresie wyboru inwestorów strategicznych i włączenia się w międzynarodowe, aktywne i pasywne sieci powiązań technologicznych, rynkowych, organizacyjnych i kapitałowych.

\section{Literatura}

Bałtowski M. 2002, Przeksztatcenia własnościowe przedsiębiorstw państwowych w Polsce, PWN, Warszawa

Bazydło A., Smętkowski M. 2000, Specjalne strefy ekonomiczne - światowe zróżnicowanie instrumentu, [w:] Polskie Specjalne Strefy Ekonomiczne - zamierzenia i efekty, red. E. Kryńska, Scholar, Warszawa, s. 56-85

Bazydło A., Smętkowski M., Wieloński A. 2001, Inwestycje w specjalnych strefach ekonomicznych a przekształcenia strukturalne w przemyśle Polski, [w:] Problemy przemian struktur przemystowych w procesie wdrażania regut gospodarki rynkowej, red. Z. Zioło, Prace Komisji Geografii Przemysłu PTG nr 3, Warszawa-Kraków-Rzeszów, s. 135-148

Czapliński P. 2000, Przemyst drzewny na Pomorzu Środkowym w procesie przeobrażeń gospodarczych, [w:] Problemy transformacji struktur przemystowych w procesie przechodzenia do gospodarki rynkowej, red. Z. Zioło, Prace Komisji Geografii Przemysłu PTG nr 1, Warszawa-Kraków, s. $67-76$

Domański B. 2001, Kapitał zagraniczny w przemyśle Polski, Instytut Geografii i Gospodarki Przestrzennej UJ, Kraków

Dowżycki A., Sobolewski H., Tłuchowski W. 2001, Restrukturyzacja, prywatyzacja i wycena przedsiębiorstwa, Akademia Ekonomiczna w Poznaniu, Poznań

Gierańczyk W. 2000, Wpływ transformacji ustrojowej na zmiany strukturalne w przemyśle województwa toruńskiego, [w:] Problemy transformacji struktur przemystowych w procesie przechodzenia do gospodarki rynkowej, red. Z. Zioło, Prace Komisji Geografii Przemysłu PTG nr 1, WarszawaKraków, s. 77-88

Godziszewski B. 2001, Szanse i zagrożenia dla polskich przedsiębiorstw zwiqzane z Uniq Europejska, [w:] Konkurencyjność gospodarki Polski w dobie integracji z Uniq Europejskq i globalizacji, t. II, SGH, Warszawa, s. 281-293

Jakóbik W. 1993, Restrukturyzacja przemystu w okresie transformacji, Fundacja im. F. Eberta, Warszawa

Jurek-Stępień S. 1994, Struktury własnościowe. Proces prywatyzacji w przemyśle, [w:] Restrukturyzacja polskiego przemystu - dostosowania, SGH, Warszawa, s. 68-79

Karpiński A. 1986, Restrukturyzacja gospodarki w Polsce i na świecie, PWE, Warszawa

Kortus B. 1992, Wprowadzenie do problematyki badań nad restrukturyzacja przemystu, Folia Geographica, Series Geographica-Oeconomica, vol. XXIV, KNG PAN - Oddz. w Krakowie, Wrocław-Warszawa-Kraków, s. 7-11 
Kotowicz-Jawor J. 1997, Bariery rozwoju przedsiębiorstw w okresie transformacji, [w:] Transformacja gospodarki. Spojrzenie retrospektywne, red. W. Jakóbik, Instytut Studiów Politycznych PAN i Fundacja im. F. Eberta, Warszawa

Koźmiński A.K. 1998, Odrabianie zaległości. Zmiany organizacji i zarzq̨dzania w byłym bloku socjalistycznym, PWN, Warszawa

Kudełko J. 1997, Uwarunkowania prawne inwestycji zagranicznych w Polsce, [w:] Problemy transformacji struktur przemystowych w procesie przechodzenia do gospodarki rynkowej, red. Z. Zioło, Komisja Geografii Przemysłu PTG, Instytut Geografii WSP w Krakowie, Warszawa-Kraków, s. $151-168$

Kuźnik F. 2000, Regionalna struktura, skala i specyfika procesów restrukturyzacji przemyslu z określeniem obszarów problemowych z punktu widzenia strategii rozwoju regionalnego $w$ latach 2000-2006, [w:] Narodowa Strategia Rozwoju Regionalnego, red. J. Szlachta, Biuletyn KPZK PAN, nr 191, Warszawa, s. 299-320

Liberska B. 2002a, Wspótczesne procesy globalizacji gospodarki światowej, [w:] Globalizacja: mechanizmy $i$ wyzwania, red. B. Liberska, PWE, Warszawa, s. 17-37

Liberska B. 2002b, Udziat Polski w procesach globalizacji, [w:] Globalizacja: mechanizmy $i$ wyzwania, red. B. Liberska, PWE, Warszawa, s. 320-334

Makieła Z., Troc M. 1992, Tendencje przemian przestrzenno-gatęziowych przemystu w Górnoślaskim Okregu Przemysłowym w latach 1975-1988, Folia Geographica, Series Geographica-Oeconomica, vol. XXIV, Wrocław-Warszawa-Kraków, s. 53-65

Mikołajewicz Z. 1995, Procesy restrukturyzacji przemystu w regionach, Uniwersytet Opolski, Opole

Mikołajewicz Z. 2001, Przedmiotowa struktura inwestycji przemysłowych wyrazem przemian strukturalnych w polskim przemyśle, [w:] Problemy przemian struktur przestrzennych przemystu, red. Z. Zioło, Prace Komisji Geografii Przemysłu PTG nr 2, Warszawa-Kraków, s. 21-34

Misztal S. 1993, Regionalne zróżnicowanie procesu prywatyzacji przemystu w Polsce, „Przegląd Geograficzny", t. LXV, z. 3-4, s. 255-277

Misztal S. 1994, Wpływ wielkości zakładów i przedsiębiorstw przemystowych na ich funkcjonowanie w okresie przejściowym do gospodarki rynkowej, [w:] Funkcjonowanie przedsiębiorstw przemysłowych $w$ zmieniajacych się warunkach gospodarowania, red. Z. Zioło, COMSN, Komisja Geografii Przemysłu PTG, Kraków-Warszawa, s. 164-171

Misztal S. 2000, Regionalne efekty procesu prywatyzacji przemystu w Polsce w latach 1989-1995, [w:] Problemy transformacji struktur przemyslowych $w$ procesie przechodzenia do gospodarki rynkowej, red. Z. Zioło, Prace Komisji Geografii Przemysłu PTG nr 1, Warszawa-Kraków, s. 23-34

Misztal S. 2003, Transformacja własnościowa działalności przemysłowej w Polsce wedtug województw, [w:] Kształtowanie się struktur przemysłowych, red. Z. Zioło, Z. Makieła, Prace Komisji Geografii Przemysłu PTG nr 5, Warszawa-Kraków, s. 9-30

Nalepka A. 2000, Ustalanie i ocena skutków restrukturyzacji przedsiębiorstwa, [w:] Strategie wzrostu produktywności firmy. Materiały konferencji naukowej (Zakopane-Kościelisko, 22-24 IX 2000 r.), red. A. Stabryła, Akademia Ekonomiczna, Kraków, s. 409-418

Nalepka A. 1997, Istota, zakres i metodyka restrukturyzacji przedsiębiorstwa, [w:] Restrukturyzacja a konkurencyjność przedsiębiorstw, red. R. Borowiecki, Akademia Ekonomiczna, Kraków

Nalepka A. 1998, Zarys problematyki restrukturyzacji przedsiębiorstw, Antykwa, Kraków

Nowak E. red. 2001, Metody statystyczne w analizie działalności przedsiębiorstwa, PWE, Warszawa

Pakuła L. 1967, Uwagi o prowadzeniu ćwiczeń terenowych z geografii przemystu, [w:] Wybrane zagadnienia z metodyki ćwiczeń terenowych z geografii ekonomicznej, Prace z Dydaktyki Szkoły Wyższej, z. 4, Wydawnictwo Naukowe WSP, Kraków

Pakuła L. 1992, Postęy restrukturyzacji przemystu $w$ wybranych gałęziach przemystu $w$ okregach Górnoślaskim, Częstochowskim i Bielskim, Folia Geographica, Series Geographica-Oeconomica, vol. XXIV, Wrocław-Warszawa-Kraków, s. 37-49 
Pakuła L. 2003, Tendencje restrukturyzacji przemystu Górnoślaskiego Okręgu Przemystowego w dobie transformacji, [w:] Przemyst w procesie globalizacji, Prace Komisji Geografii Przemysłu PTG nr 6, red. Z. Zioło i Z. Makieła, Warszawa-Kraków, s. 59-66

Parysek J.J. 1992a, Polski przemyst a nowe warunki społeczno-ustrojowe, [w:] Studia geograficzne przemian społeczno-gospodarczych, red. Z. Chojnicki, Biuletyn KPZK PAN, z. 159, s. 75-88

Parysek J.J. 1992b, Dobrodziejstwo inwentarza czyli jak zrestrukturyzować przemyst Polski, [w:] Geografia przemystu $w$ warunkach nowego systemu gospodarowania - problemy badawcze $i$ odzwierciedlenie ich $w$ kształceniu nauczycieli, red. Z. Zioło, COMSN, WSP w Krakowie, Komisja Geografii Przemysłu PTG, Kraków-Warszawa, s. 28-45

Pasieczny J. 1997, Restrukturyzacja - wczoraj, dziś i jutro, [w:] Restrukturyzacja a konkurencyjność przedsiębiorstw, red. R. Borowiecki, Akademia Ekonomiczna, Kraków

Pączka S. 1994a, Badania dotyczqce funkcjonowania przedsiębiorstw przemysłowych w zmieniajqcych się warunkach gospodarowania w Polsce, [w:] Funkcjonowanie przedsiębiorstw przemystowych w zmieniajacych się warunkach gospodarowania, red. Z. Zioło, COMSN, Komisja Geografii Przemysłu PTG, Kraków-Warszawa, s. 172-187

Pączka S. 1994b, Problematyka badawcza zachowań przestrzennych przemystu $w$ zmieniajacych sie warunkach gospodarowania w Polsce, [w:] Zachowania przestrzenne przemystu w zmieniajacych się warunkach gospodarowania, red. Z. Zioło, COMSN, Komisja Geografii Przemysłu PTG, Kraków-Warszawa, s. 39-47

Pełka B. 1995, Polityka, strategie i restrukturyzacja przemystu w systemie gospodarczym, Instytut Organizacji i Zarządzania w Przemyśle „Orgmasz”, Warszawa

Rachwał T. 2001a, Problematyka kwestionariusza do badań zmian funkcjonowania przedsiębiorstwa przemystowego $w$ okresie transformacji systemu gospodarowania, [w:] Problemy przemian struktur przestrzennych przemystu, red. Z. Zioło, Prace Komisji Geografii Przemysłu PTG nr 2, Warszawa-Kraków, s. 49-57

Rachwał T. 2001b, Funkcjonowanie Krakowskich Zakładów Elektronicznych „,TELPOD” w świetle przemian $w$ polskim przemyśle elektronicznym, [w:] Problemy przemian struktur przemystowych w procesie wdrażania regut gospodarki rynkowej, red. Z. Zioło, Prace Komisji Geografii Przemysłu PTG nr 3, Warszawa-Kraków-Rzeszów, s. 167-180

Rachwał T. 2001c, Proces restrukturyzacji Zaktadów Mięsnych „Nisko” S.A. jako potencjalny czynnik aktywizacji rolniczej bazy surowcowej pótnocnej części województwa podkarpackiego, [w:] Problemy przemian struktur przemystowych $w$ procesie wdrażania regut gospodarki rynkowej, red. Z. Zioło, Prace Komisji Geografii Przemysłu PTG nr 3, Warszawa-Kraków-Rzeszów, s. $181-189$

Rachwał T. 2003, Globalne uwarunkowania restrukturyzacji przedsiębiorstw przemysłowych Polski Poludniowo-Wschodniej, [w:] Przemyst w procesie globalizacji, red. Z. Zioło, Z. Makieła, Prace Komisji Geografii Przemysłu PTG nr 6, Warszawa-Kraków, s. 129-138

Rapacki R. 1994, Spoleczno-polityczne uwarunkowania i konsekwencje procesu transformacji systemowej w Polsce, „Gospodarka Narodowa”, nr 1(48), s. 1-13

Rochnowski H. 2000, Niektóre kierunki, cele i uwarunkowania przemystu Polski w okresie transformacji, [w:] Problemy transformacji struktur przemystowych w procesie przechodzenia do gospodarki rynkowej, red. Z. Zioło, Prace Komisji Geografii Przemysłu PTG nr 1, Warszawa-Kraków, s. $45-54$

Rydz E., Jażewicz I. 2001, Przemiany strukturalne przemystu na przykladzie małych miast Pomorza Środkowego, [w:] Problemy przemian struktur przemystowych $w$ procesie wdrażania regut gospodarki rynkowej, red. Z. Zioło, Prace Komisji Geografii Przemysłu PTG nr 3, WarszawaKraków-Rzeszów, s. 71-86

Sapijaszka Z. 1997, Restrukturyzacja przedsiębiorstwa. Szanse i ograniczenia, PWN, Warszawa

Stępień B. 2001, Procesy przystosowawcze przedsiębiorstw postsocjalistycznych do warunków rynkowych, Akademia Ekonomiczna, Poznań 
Stryjakiewicz T. 1999, Adaptacja przestrzenna przemyslu $w$ Polsce $w$ warunkach transformacji, Wydawnictwo Naukowe UAM, Poznań

Sudoł S. 1997, Perspektywy rozwoju polskich przedsiębiorstw przemystowych i budowlanych, „Ekonomika i Organizacja Przedsiębiorstwa”, nr 8 (571), s. 4-6

Sudoł S., Matuszak M. red. 2002, Przyczyny rozwoju i upadku polskich przedsiębiorstw przemysłowych w okresie transformacji ustrojowej 1990-1998, Wydawnictwo UMK, Toruń

Szczepkowska M. 2003, Funkcjonowanie przedsiębiorstw w ramach grup kapitałowych na przykładzie Narodowych Funduszy Inwestycyjnych, [w:] Przemiany i perspektywy polskich przedsiębiorstw $w$ dobie integracji z Uniq Europejska, red. K. Piech i G. Szczodrowski, Instytut Wiedzy, Warszawa, s. 201-214

Tkocz M. 2001, Restrukturyzacja przemystu regionu tradycyjnego, Uniwersytet Śląski, Katowice

Tobolska A. 2004, Zmiany własnościowe i organizacyjno-ekonomiczne w wybranych dużych przedsiębiorstwach przemystowych Poznania w okresie transformacji, Wydawnictwo Naukowe UAM, Poznań

Wieloński A., Durydiwka M. 1994, Przemyst w Polsce w warunkach przejścia do gospodarki rynkowej i integracji z Europq Zachodnia, „Czasopismo Geograficzne”, LXV, z. 3-4, s. 317-325

Wojtyna A. 1994, Polityka przemystowa a instytucjonalne ramy restrukturyzacji w Polsce, Gospodarka Narodowa nr 12 (56), s. 6-14

Zioło Z. 1992, Wzrost i struktura przestrzenna przemysłu województwa krakowskiego w latach 19751988, Folia Geographica, Series Geographica-Oeconomica, vol. XXIV, Wrocław-WarszawaKraków, s. 69-76

Zioło Z. 1994, Zmiany otoczenia przedsiębiorstw przemystowych w nowych warunkach gospodarowania, [w:] Funkcjonowanie przedsiębiorstw przemystowych $w$ zmieniajacych się warunkach gospodarowania, red. Z. Zioło, COMSN, Komisja Geografii Przemysłu PTG, Kraków-Warszawa, s. $13-21$

Zioło Z. 1996a, Oddziaływanie procesów transformacji gospodarki narodowej na funkcjonowanie jednostek gospodarczych, [w:] Wpływ procesów transformacji gospodarki narodowej na funkcjonowanie jednostek gospodarczych i układów przestrzennych, red. Z. Zioło, Komisja Geografii Przemysłu PTG, Instytut Geografii WSP w Krakowie, Warszawa-Kraków, s. 146-151

Zioło Z. 1996b, Model funkcjonowania przestrzeni geograficznej i jej znaczenie dla gospodarki przestrzennej, [w:] Gospodarka, przestrzeń, środowisko, red. U. Wich, Wydawnictwo UMCS, Lublin, s. $183-191$

Zioło Z. 1999, Model funkcjonowania przestrzeni geograficznej jako próba integracji badań geograficznych, [w:] Geografia na przełomie wieków-jedność w różnorodności, red. A. Lisowski, UW, Warszawa

Zioło Z. 2003, Ksztaltowanie się przedsiębiorstw przemyslowych w procesie globalizacji, [w:] Przemyst w procesie globalizacji, red. Z. Zioło, Z. Makieła, Prace Komisji Geografii Przemysłu PTG nr 6, Warszawa-Kraków, s. 9-20

Zorska A. 1998, Ku globalizacji? Przemiany w korporacjach transnarodowych $i$ w gospodarce światowej, PWN, Warszawa

Żukrowska K. 2001, Polska gospodarka w warunkach globalizacji gospodarki światowej, [w:] Globalizacja, red. J. Klich, Wydawnictwo PSB, Kraków, s. 149-172

\section{Effects of restructurings of industrial enterprises in south-east Poland}

The subject of this paper is restructuring of industrial enterprises of south-east Poland in the period of economic transformation. These enterprises represent different types of largeness, ownership and sections of industrial production. They fulfil different functions in the economic structure, and most 
of them fulfil international functions or national functions with exporting part of the production for international markets. The purpose of this research is presenting the regularities and types of functioning of enterprises influenced by external and internal conditions. The research problems include: changes of ownership and organizational structure, changes of level and structure of employment, changes of technological processes and assortment of production, spatial changes in the directions of provision and sales, changes in the structure of costs, financial results and perspectives of development. 